\title{
Sensitivitas Makroekonomi dan Moneter Terhadap IHSG
}

\author{
Reza Widhar Pahlevi \\ Jurusan Manajemen Fakultas Ekonomi Universitas Islam Indonesia (UII) Yogyakarta \\ Jl. Prawiro Kuat, Ngringin, Condongcatur, Yogyakarta,55283, Indonesia
}

Info Article Abtract

Keywords:

Composite Stock Price Index;

Dollar Exchange Rate; Inflation

Rate; SBI; The Money Supply.

ISSN (print) : 2598-7763

ISSN (online): 2598-7771

$\triangle$ Corresponding Author:

Reza Widhar Pahlevi:

Tel. /Fax. 0817276108

E-mail: rezawp@uii.ac.id
This study aims to examine the sensitivity of the dollar exchange rate of the dollar (USD), inflation rate, SBI and the money supply against the Composite Stock Price Index. The study sample used Monthly data in the period January 1, 2008 to January 1, 2018, which data was obtained from the monthly report of Bank Indonesia. The research method used is a quantitative approach, namely Error Correction Model (ECM) with EViews software. The results showed that the dollar (USD) exchange rate was sensitive to the Composite Stock Price Index, SBI was not sensitive to the Composite Stock Price Index, the money supply was sensitive to the Composite Stock Price Index and the inflation rate was sensitive to the Composite Stock Price Index

Citation: Pahlevi, Reza Widhar (2019). Sensitivitas Makroekonomi dan Moneter Terhadap IHSG. AFRE Accounting and Financial Review, 2 (1)

\begin{abstract}
Abstraks Gabungan.

JEL Classification: E44, E51

DOI: https://doi.org/10.26905/afr.v2i1.3018
\end{abstract}

Penelitian ini bertujuan untuk menguji sensitivitas kurs rupiah dollar (USD), SBI, jumlah uang beredar dan tingkat inflasi terhadap Indeks Harga Saham Gabungan. Sampel penelitian digunakan data Bulanan pada periode 1 Januari 2008 hingga 1 Januari 2018 yang data tersebut diperoleh dari laporan bulanan Bank Indonesia. Metode penelitian yang digunakan adalah pendekatan kuantitatif, yaitu Error Correction Model (ECM) dengan software E-Views. Hasil penelitian menunjukkan bahwa kurs rupiah dollar (USD) sensitif terhadap Indeks Harga Saham Gabungan, SBI tidak sensitif terhadap Indeks Harga Saham Gabungan, jumlah uang beredar sensitif terhadap Indeks Harga Saham Gabungan serta tingkat inflasi sensitif terhadap Indeks Harga Saham

\section{PENDAHULUAN}

Indeks Harga Saham Gabungan mengalami penurunan karena disebabkan kondisi perekonomian Negara yang mengalami permasalahan, sedangkan meningkanya Indeks Harga Saham Gabungan adalah indikasi peningkatan kinerja perekonomian suatu Negara. Harga saham pada suatu Negara akan terbentuk tidak hanya dipengaruhi oleh kondisi bisnis dan perekonomian Negara tetapi juga dipengaruhi oleh kondisi bisnis dan perekonomian Negara lain. Kondisi bisnis suatu negara akan berdampak pada harga saham di pasar modal suatu negara. Globalisasi perekonomian du- nia telah membuat perekonomian cenderung teringrasi dan ada ketergantungan dan keterkaitan perekonomian antar negara. Kondisi perekonomian dunia akan berdampak pula pada suatu pasar saham. Pasar saham antar negara cenderung akan saling berhubungan. Temuan penelitian Anriansyah, Siregar dan Maulana (2018) menunjukkan bahwa adanya hubungan kausalitas antara pasar saham di ASEAN.

Fundamental ekonomi akan berdampak pada perusahaan. Perusahaan akan mampu berkembang dengan baik, jika fundamental ekonomi suatu negara kuat. Fundamental ekonomi antara lain tingkat pertumbuhan ekonomi, stabilitas ekonomi 
atau ijnflasi, tingkat suku bunga, tingkat kurs dan tingkat pendapatan masyarakat.

Bagi investor yang cenderung orientasinya jangka panjang, fundamental ekonomi menjadi informasi penting. Investor di pasar modal ada bukan hanya berorintasi jangka pendek, tetapi juga ada investor yang berorientasi jangka panjang. Sehingga fundamental ekonomi tidak selalu berdampak langsung pada pasar. Pasar belum tentu akan merespon secara cepat perubahan makroekonomi suatu negara. Temuan penelitian terkait dengan makroekonomi dan respon pasar, yang ditunjukkan dengan indeks harga saham menunjukkan hasil yang tidak konsisiten.

Faktor domestik seperti inflasi, pendapatan nasional, jumlah uang yang beredar, suku bunga, dan nilai tukar adalah merupakan indikator fundamental perekonomian suatu negara. Fundamental ekonomi akan mempengaruhi Indeks Harga Saham Gabungan. Selain itu faktor fundamental seperti tingkat ekspektasi investor berpengaruh pada pergerakan indeks. Faktor asing juga merupakan salah satu dampak dari globalisasi dan apabila semakin terintegrasinya pasar modal di seluruh dunia maka kondisi ini akan menimbulkan dampak penggerak dari bursa maju terhadap bursa yang sedang berkembang (Maryanne, 2009).

Saputra dan Harjito (2015) berpendapat bahwa faktor fundamental ekonomi yang salah satunya nilai tukar valuta asing lebih dominan untuk dikaji dan diteliti. Nilai tukar valuta asing yang berfluktuatif akan mempunyai hubungan dengan sektor rill. Fenomena nilai tukar valuta asing yang berfluktuatif akan berdampak langsung pada tingkat inflasi, dan sebaliknya. Hubungan yang saling terkait antara kurs valuta asing, Indeks Harga Saham Gabungan dan dan tingkat inflasi merupakan sebuah fenomena yang kontroversial. Perdebatan pembahasan mengenai kurs valuta asing, Indeks Harga Saham Gabungan dan dan tingkat inflasi adalah apakah kurs valuta asing mempengaruhi Indeks Harga Saham Gabungan dan tingkat inflasi atau sebaliknya, Indeks Harga Saham Gabungan dan tingkat inflasi yang mempengaruhi kurs valuta asing. Sampai saat ini belum ada kejelasan rasional tentang bagaimana hubungan antar variabel tersebut.

Kurs suatu mata uang yang semakin kuat, menunjukkan fundamental perekonomian suatu negara semakin baik. Perubahan kurs akan berdampak pada kondisi perusahaan. Perusahaan dengan sumber pendanaan dalam bentuk mata uang asing, maka perubahan kurs akan berdampak pada beban beban hutang. Demikian halnya perusahaan dengan sumber bahan baku import atau penjualan yang berorintasi eksport, maka perubahan kurs akan berdampak pada keuangan perusahaan. Sehingga akan berdampak pada kinerja perusahaan. Hal ini membuat perubahan kurs akan berdampak pada harga saham. Hasil penelitian Adisetiawan (2018) dan Suselo, Djazuli dan Indrawati (2015) menunjukkan sensivitas kurs berpengaruh negatif terhadap harga saham. Sedangkan temuan penelitian Karim, Hermanto dan Ardana (2018) menunjukkan bahwa kurs tidak berpengaruh terhadap ekspektasi investor, yang ditunjukkan dari nilai perusahaan.

Penelitian terkait dengan hubungan antara suku bunga dengan indeks harga saham menunjukkan hasil yang tidak konsisten. Penelitian Martinez, Lapena dan Sotos (2015), Artha, Achsani dan Sasongko (2014) menunjukkan bahwa SBI berpengaruh terhadap harga saham. Sedangkan temuan Adisetiawan (2018), Bahloul, Mroua, and Naifar (2017), dan Suselo, Djazuli dan Indrawati (2015) menunjukkan hasil yang berbeda, suku Bungan SBI tidak berpengaruh terhadap indeks harga saham.

Kesesuaian jumlah uang beredar dengan kebutuhan akan berdampak pada harga barang. Jika jumlah uang terlalu tinggi, akan cenderung memicu kenaikkan harga barang. Jumlah uang beredar akan terkait dengan kelancaran transaksi. Temuan penelitian menunjukkan ada hubungan kausualitas antara jumlah uang beredar dengan indeks harga saham gabungan (Adisetiwan, 2018).

Bahloul, Mroua, and Naifar (2017) menunjukkan bahwa inflasi mempunyai pengaruh yang berbeda di developed market dan emerging market. Inflasi di developed market berpengruh terhadap indeks harga saham. Sedangkan di emerging market, inflasi tidak berpengaruh terhadap indeks harga saham. Sedangkan penelitian Suselo, Djazuli dan Indrawati (2015), Atik (2012), Ramadhan (2011) dan Adaramola dan Olugbenga (2011) menunjukkan bahwa inflasi berpengaruh terhadap indeks. Penelitian Adisetiawan (2018) menunjukkan inflasi tidak berpengaruh terhadap indeks harga saham.

Penelitian ini akan mengkaji mengenai faktor yang diduga akan mempengaruhi tingkat sensitifitas Indeks Harga Saham Gabungan. Faktor makro yang mempengaruhi aktivitas investasi saham di Bursa Efek Indonesia, antara lain adalah tingkat inflasi, tingkat suku bunga SBI (Sertifikat Bank Indonesia), nilai kurs valuta asing, dan jumlah uang beredar. Tingginya tingkat inflasi yang terjadi akan menurunkan daya beli masyarakat dan meningkatnya harga faktor produksi. Sehingga berdampak pada anggapan pesimis mengenai prospek perus- 
ahaan yang menghasilkan barang atau jasa yang terkena dampak inflasi tersebut yang akhirnya dapat mempengaruhi penawaran harga saham perusahaan tersebut dan pada akhirnya berakibat pada pergerakan indeks harga saham di Bursa Efek Indonesia. Selain itu jika suku bunga Sertifikat Bank Indonesia yang ditetapkan meningkat maka investor akan mendapat imbal hasil yang lebih besar atas suku bunga deposito yang ditanamkan sehingga investor akan cenderung mendepositokan modalnya dibandingkan melakukan investasi dalam sekuritas saham. Sehingga akan mengakibatkan investasi di pasar modal akan semakin turun yang pada akhirnya akan berakibat pada melemahnya Indeks Harga Saham Gabungan.

Tujuan penelitian ini adalah: 1) untuk menganalisis tingkat sensitivitas Kurs Rupiah dan Dollar terhadap IHSG; 2) untuk menganalisis tingkat sensitivitas SBI (Sertifikat Bank Indonesia) terhadap IHSG; 3) untuk menganalisis tingkat sensitivitas Jumlah Uang Beredar terhadap IHSG serta 4) untuk menganalisis tingkat sensitivitas Tingkat Inflasi terhadap IHSG.

\section{PENGEMBANGAN HIPOTESIS}

\section{Indeks Harga Saham Gabungan (IHSG) sensitif terhadap perubahan Kurs Rupiah dan Dollar}

Peneliti mengkaji dari hasil penelitian sebelumnya, teori-teori dan fenomena yang terjadi. Penelitian yang dilakukan oleh Murtini dan Septivanie (2016) menunjukkan bahwa Indeks Harga Saham Gabungan sensitif terhadap perubahan kurs valuta asing (USD, JPY, CNY) dan SBI. Indeks Harga Saham Gabungan sensitif negatif terhadap kurs valuta asing (CNY) dan SBI, dan Indeks Harga Saham Gabungan sensitif positif terhadap kurs valuta asing (USD dan JPY). Penelitian yang dilakukan oleh Divianto (2013) menunjukkan bahwa inflasi, tingkat bunga SBI dan nilai tukar secara simultan berpengaruh signifikan terhadap Indeks Harga Saham Gabungan. Sedangkan menurut Kasman, et al. (2011) menunjukkan bahwa tingkat suku bunga dan perubahan nilai tukar memiliki dampak negatif dan signifikan terhadap pengembalian saham bank. Hasil lebih lanjut menunjukkan bahwa suku bunga dan volatilitas nilai tukar ditemukan menjadi faktor penentu utama dalam volatilitas return saham bank. Oleh karena itu, bukti ini menunjukkan bahwa variasi dalam suku bunga dan risiko nilai tukar dapat menjelaskan karakteristik bank yang dapat diamati relevan untuk pihak yang berkepentingan yang ingin mengelola eksposur risiko mereka dan mengawasi perubahan dalam eksposur.

$\mathrm{H}_{1}$ : Indeks Harga Saham Gabungan (IHSG) sensitif terhadap perubahan Kurs Rupiah dan Dollar.

\section{Indeks Harga Saham Gabungan (IHSG) sensitif terhadap perubahan SBI}

Hasil kajian Maryanne (2009) memberikan temuan bahwa tidak ada pengaruh antara nilai tukar rupiah terhadap harga saham. Tidak adanya pengaruh yang signifikan ini disebabkan karena sektor perbankan menggunakan mata uang rupiah dalam melakukan transaksi dengan nasabah sehingga nilai tukar rupiah terhadap dollar tidak berpengaruh pada harga saham perusahaan. Hasil temuan selanjutnya diperoleh bahwa ada pengaruh yang signifikan dan negatif antara suku bunga SBI terhadap harga saham secara parsial. Para investor cenderung berspekulasi dalam menanamkan investasi ke perusahaan yang mempunyai risiko yang lebih tinggi, dengan harapan memperoleh keuntungan yang tinggi pula dari saham yang dibelinya.

$\mathrm{H}_{2}$ : Indeks Harga Saham Gabungan (IHSG) sensitif terhadap perubahan SBI

\section{Indeks Harga Saham Gabungan (IHSG) sensitif terhadap perubahan Jumlah Uang Beredar}

Nguyen (2015) menunjukkan hasil penelitian bahwa tingkat inflasi yang tinggi akan mempengaruhi perekonomian secara drastis, tetapi ada beberapa bukti menunjukkan jika inflasi moderat akan memperlambat pertumbuhan ekonomi. Tingkat inflasi yang tinggi tidak hanya berasal dari instrumen kebijakan moneter (seperti uang beredar, tingkat bunga) tetapi juga dipengaruhi oleh dampak kebijakan fiskal (defisit fiskal, pengeluaran pemerintah). Defisit fiskal menjadi salah satu pendorong utama tingginya tingkat inflasi. Sebagian besar negara Asia memiliki tingkat defisit fiskal dan uang beredar relatif tinggi hal ini disebabkan karena pemerintah akan meningkatkan belanja untuk mendorong pertumbuhan ekonomi dan menciptakan lapangan kerja.

$\mathrm{H}_{3}$ : Indeks Harga Saham Gabungan (IHSG) sensitif terhadap perubahan Jumlah Uang Beredar

\section{Harga Saham Gabungan (IHSG) sensitif terhadap perubahan Tingkat Inflasi}

Binnera et al. (2010) mengemukakan bahwa hubungan antara uang beredar dan inflasi telah menjadi semakin penting selama krisis keuangan 
baru-baru ini karena pada sejumlah negara, instrumen kebijakan moneter telah bergeser ke arah jumlah uang beredar dan jauh dari suku bunga overnight (misalnya, Suku Bunga Bank di Inggris; tingkat dana federal di Amerika Serikat).

$\mathrm{H}_{4}$ : Harga Saham Gabungan (IHSG) sensitif terhadap perubahan Tingkat Inflasi

\section{DATA DAN METODE}

Penelitian ini menggunakan data sekunder Data yang digunakan bersumber dari situs resmi BI (bi.go.id) dan Galeri Investasi Bursa Efek Indonesia di Universitas Islam Indonesia. Data pengamatan menggunakan periode bulanan sejak 1 Januari 2008 hingga 1 Januari 2018.

\section{Operasionalisasi Variabel Penelitian}

Definisi operasional variabel penelitian menunjukkan ukuran atau proksi dari suatu variabel. Variabel bebas pada penelitian ini menggunakan nilai tukar rupiah dan dollar, tingkat suku bunga SBI, tingkat inflasi, serta jumlah uang beredar. Sedangkan variabel terikat pada penelitian ini menggunakan Indeks Harga Saham Gabungan. Variabel Nilai Tukar Rupiah dan Dollar digunakan nilai kurs tengah yang ditetapkan berdasarkan harga kurs oleh Bank Indonesia periode Bulan Januari 2008 sampai dengan Bulan Januari 2018. Suku Bunga Sertifikat Bank Indonesia, diukur dengan tingkat suku bunga yang ditetapkan oleh Bank Indonesia periode Bulan Januari 2008 sampai dengan Bulan Januari 2018. Vaiabel inflasi diukur dengan menggunakan data bulanan periode Bulan Januari 2008 sampai dengan Bulan Januari 2018. Jumlah uang yang beredar digunakan dari volume peredaran uang perbulan selama 10 tahun. Sedangkan Indeks Harga Saham Gabungan (IHSG) adalah indeks harga yang merupakan gabungan semua harga saham yang tercatat di Bursa Efek Indonesia (BEI), pengukuran yang dilakukan adalah dalam satuan poin.

Teknik analisis deskriptif merupakan analisis berbentuk uraian dari hasil penelitian yang didu- kung dengan teori data yang telah ditabulasi, kemudian diikhtisarkan (Sugiyono, 2010). Metode deskriptif ini berupa gambaran data yang berhubungan dengan Kurs Rupiah dan Dollar, Tingkat Inflasi, Sertifikat Bank Indonesia, Jumlah Uang Beredar dan Indeks Harga Saham Gabungan.

Penelitian ini menggunakan pendekatan secara kuantitatif melalui analisis inferensial untuk menganalisis data penelitian dan menarik kesimpulan melalui pengujian hipotesis. Untuk menjawab hipotesis penelitian maka alat analisis yang digunakan dalam penelitian ini adalah Error Correction Model (ECM). Adapun persamaan Indeks Harga Saham Gabungan yang akan digunakan dalam penelitian Error Correction Model adalah sebagai berikut:

$I H S G=\beta_{0}+\beta_{1 \mathrm{USD}}+\beta_{2 \mathrm{SBI}}+\beta_{3 \mathrm{MI}}+\beta_{4 \mathrm{INF}}+$ ect.....

Keterangan: IHSG = Indeks Harga Saham Gabungan; USD= Kurs Rupiah dan Dollar; SBI = Sertifikat Bank Indonesia; $\mathrm{MI}=$ Jumlah Uang Beredar; INF = Tingkat Inflasi dan $\beta_{1}, \ldots, \beta_{4}=$ Koefisien regresi

\section{HASIL}

\section{Deskriptif Statistik}

Berdasarkan hasil pengolahan data penelitian Kurs Rupiah dan Dollar, Tingkat Inflasi, Sertifikat Bank Indonesia, Jumlah Uang Beredar dan Indeks Harga Saham Gabungan dengan sampel data pengamatan periode 1 Januari 2008 sampai 1 Januari 2018 dan didapat hasil statistik deskriptif seperti yang ditampilkan pada tabel 1. Pada tabel 1 menunjukkan jumlah data setiap variabel yang diolah 121 data. Selama periode penelitian nilai jumlah uang beredar mengalami peningkatan dibandingkan dengan peningkatan variabel lainnya. Hal ini dapat dilihat dari penurunan (minimum) dan kenaikan (maksimum). Penyebaran data paling besar juga pada variabel jumlah uang beredar.

Tabel 1. Statistik Deskriptif

\begin{tabular}{lccccc}
\hline & EXRATE & INFLASI & SBI & M1 & IHSG \\
\hline Mean & 10813,63 & 0,056891 & 0,073788 & 812284,9 & 3758,404 \\
Maximum & 14650,00 & 0,121400 & 0,112400 & 1390807, & 6605,630 \\
Minimum & 1327,500 & 0,024100 & 0,061900 & 456787,0 & 747,0000 \\
Std. Dev. & 2223,453 & 0,023322 & 0,013886 & 268962,9 & 1526,451 \\
Observations & 121 & 121 & 121 & 121 & 121 \\
\hline
\end{tabular}

Sumber : Data diolah 


\section{Uji Stasioneritas}

Tabel 2. Hasil Uji Stasionaritas

\begin{tabular}{lcccc}
\hline \multicolumn{1}{c}{ Variabel } & Nilai Hitung & Critical Value $(\alpha=5 \%)$ & Probabilitas & Kesimpulan \\
\hline EXRATE & $-7,740082$ & $-2,886732$ & 0,0000 & Stasioner \\
INFLASI & $-7,740082$ & $-3,486064$ & 0,0000 & Stasioner \\
SBI & $-4,440894$ & $-2,885654$ & 0,0004 & Stasioner \\
M1 & $-8,580044$ & $-2,886509$ & 0,0000 & Stasioner \\
IHSG & $-9,588450$ & $-2,885863$ & 0,0000 & Stasioner \\
\hline
\end{tabular}

Berdasarkan hasil uji stasionaritas data dapat dilihat pada tabel 2 menunjukkan semua variabel penelitian stasioner pada tingkat first difference. Variabel penelitian stasioner karena nilai probabilitas lebih kecil dari tingkat a (5\%). Karena semua variabel penelitian stasioner pada tingkat first difference, maka selanjutnya dilakukan uji nilai residual persamaan. Hasil uji residual dapat dilihat dalam tabel 3.

Tabel 3. Uji Nilai Residual

\begin{tabular}{|c|c|c|c|c|}
\hline & $\begin{array}{l}\text { Nilai } \\
\text { tung }\end{array}$ & $\begin{array}{l}\text { Ti-Critical } \\
(\alpha=5 \%) \\
\end{array}$ & $\begin{array}{l}\text { e } \\
\text { Probabilitas }\end{array}$ & Kesimpulan \\
\hline Residual & $-12,75480$ & $-2,886290$ & 0,0000 & Stasioner \\
\hline
\end{tabular}

Sumber : Data diolah

Hasil menunjukkan bahwa nilai probabilitas lebih kecil dari tingkat a (5\%), maka dapat disimpulkan bahwa nilai residual stasioner. Karena semua variabel dan nilai residual stasioner, maka dapat dilakukan uji kointegrasi.
Uji Kointegrasi pada penelitian ini dilakukan dengan pendekatan metode Johansen. Hasil pengujian kointegrasi dapat dilihat pada tabel 4. Berdasarkan hasil pengujian menunjukkan bahwa nilai probabilitas lebih kecil dari tingkat a $(5 \%)$, dan terdapat persamaan kointegrasi paling banyak 2 persamaan. Hal ini menunjukkan bahwa ada kointegrsi antara Kurs Rupiah dan Dollar, Tingkat Inflasi, Sertifikat Bank Indonesia, Jumlah Uang Beredar dan Indeks Harga Saham Gabungan. Dengan demikian, dapat disimpulkan ada hubungan keseimbangan dalam jangka panjang antara Kurs Rupiah dan Dollar, Tingkat Inflasi, Sertifikat Bank Indonesia, Jumlah Uang Beredar dan Indeks Harga Saham Gabungan. Namun belum tentu memiliki hubungan yang dinamis (jangka pendek). Untuk menguji adanya hubungan dinamis, maka perlu dilakukan uji selanjutnya menggunakan Error Correction Model (ECM).

\section{Uji Kointegrasi}

Tabel 4. Hasil Uji Kointegrasi dengan Metode Johansen

\begin{tabular}{ccccc}
\hline Hypothesized & & Trace & 0,05 & \\
\hline No. of CE(s) & Eigenvalue & Statistic & Critical Value & Prob. $^{*}$ \\
None & 0,222383 & 75,57995 & 69,81889 & 0,0161 \\
At most 1 & 0,131077 & 46,40345 & 47,85613 & 0,0680 \\
At most 2 & 0,124079 & 30,10531 & 29,79707 & 0,0461 \\
\hline
\end{tabular}

Sumber : Data diolah

\section{Error Correction Model (ECM)}

Hasil pengujian Error Correction Model dapat dilihat pada tabel berikut. Berdasarkan hasil pengujian menunjukkan bahwa Kurs Rupiah dan Dollar, Tingkat Inflasi, Jumlah Uang Beredar signifikan dan memiliki hubungan dinamis dengan arah positif, sedangkan untuk variabel Sertifikat Bank Indonesia tidak signifikan namun memiliki hubungan dinamis dengan arah negatif.

Tabel 5. Hasil Uji Error Correction Model

\begin{tabular}{crrrrrr}
\hline Variable & Coefficient & Std. Error & t-Statistic & Prob. & \multicolumn{1}{c}{ Kesimpulan } \\
\hline EXRATE & 0,336246 & 0,088506 & 3,799148 & 0,0002 & Signifikan \\
SBI & $-1766,372$ & 6722,167 & $-0,262768$ & 0,7932 & Tidak Signifikan \\
M1 & 0,004720 & 0,000422 & 11,17401 & 0,0000 & Signifikan \\
INFLASI & 0,293381 & 0,094045 & 3,119563 & 0,0023 & Signifikan \\
\hline Sumber
\end{tabular}

Sumber : Data diolah 


\section{PEMBAHASAN}

Kurs Rupiah dan Dollar berpengaruh positif atau memiliki hubungan dinamis terhadap Indeks Harga Saham Gabungan. Perubahan Kurs Valuta Asing Rupiah dan Dollar akan menyebabkan ketidakseimbangan Indeks Harga Saham Gabungan karena disebabkan terjadinya perubahan permintaan atau penawaran saham. Hubungan dinamis dengan arah positif berarti apabila terdapat kenaikan nilai Rupiah dan Dollar atau dengan kata lain apabila nilai Rupiah mengalami depresiasi terhadap Dollar dalam jangka pendek maka akan segera direspon oleh nilai Indeks Harga Saham Gabungan dengan peningkatan penyesuaian. Menurut Buffie, et al, (2017) kondisi ini sesuai dengan konsep teori ekonomi makro bahwa apresiasi atau depresiasi nilai tukar valuta asing akan meningkatkan atau menurunkan harga saham yang tergantung dari bentuk kegiatan usaha perusahaan. Dampak yang ditimbulkan adalah meningkatnya nilai ekspor yang akan meningkatkan pendapatan perusahaan sehingga akan menarik investor untuk melakukan investasi pada perusahaan tersebut. Sebaliknya ketika nilai Rupiah mengalami apresiasi terhadap Dollar maka Indeks Harga Saham Gabungan akan menurun, kondisi ini terjadi karena adanya intervensi kebijakan moneter pemerintah yang memicu terjadinya interaksi subsitusi antara pasar uang dan pasar modal melalui jalur nilai tukar (exchange rate channel) dan jalur suku bunga (intereset rate channel). Jika kebijakan menggunakan jalur nilai tukar, maka menguatnya rupiah merupakan dampak dari Bank Indonesia (BI) mengintervensi pasar uang dengan memperkuat valuta asing. Kebijakan tersebut dilakukan agar nilai tukar rupiah tetap stabil ditengah pelemahan rupiah lantaran money demand dollar AS cukup tinggi (Saputra dan Harjito, 2015).

Sertifikat Bank Indonesia tidak signifikan terhadap Indeks Harga Saham Gabungan namun memiliki hubungan dinamis dengan arah negatif. Hal ini terdapat kecenderungan investor untuk berspekulasi menanamkan investasi ke perusahaan yang mempunyai risiko yang tinggi, dengan harapan memperoleh imbal hasil yang tinggi. Apabila Sertifikat Bank Indonesia tinggi maka akan direspon dengan menurunnya nilai Indeks Harga Saham Gabungan. Apabila Sertifikat Bank Indonesia meningkat, maka tingkat bunga kredit juga akan meningkat. Sertifikat Bank Indonesia mempunyai dampak terhadap harga saham. Kenaikan bunga dapat meningkatkan beban perusahaan yang lebih sehingga dapat menurunkan tingkat keuntungan perusahaan. Penurunan keuntungan perusahaan akan direspon investor dengan menjual sahamnya sehingga akan menyebabkan penurunan Indeks Harga Saham Gabungan (Maryanne, 2009).

Hasil penelitian menunjukkan bahwa jumlah uang beredar memiliki hubungan dinamis terhadap Indeks Harga Saham Gabungan, apabila jumlah uang beredar mengalami peningkatan maka Indeks Harga Saham Gabungan juga akan mengalami peningkatan. Jumlah uang beredar merupakan salah satu indikator sektor moneter yang dianggap penting dan essensial. Dalam suatu penelitian mengenai jumlah uang beredar dinyatakan sebagai indikator yang memberikan sinyal positif terhadap pertumbuhan ekonomi (Boediono, 2005). Menurut Madura (2009), apabila masyarakat percaya dan menggunakan uang sebagai pembayaran untuk barang dan hutang, maka perdagangan dimu-dahkan. Menurut Mohamad (2004), jika jumlah uang beredar meningkat, maka harga saham naik, hal tersebut dikarenakan ketika jumlah uang beredar meningkat maka investor akan cendrung melakukan investasi. Ketika para investor menyimpan uang mereka untuk investasi saham maka harga saham perusahaan pun akan mengalami peningkatan sehingga berdampak pada meningkatnya Indeks Harga Saham Gabungan.

Inflasi berpengaruh positif atau memiliki hubungan dinamis terhadap Indeks Harga Saham Gabungan. Tingkat inflasi yang tinggi dikaitkan dengan kondisi ekonomi yang terlalu panas (overheated), artinya jika kondisi perekonomian mengalami permintaan atas produk yang melebihi kapasitas penawaran produknya, maka akan menyebabkan harga akan mengalami kenaikan. Inflasi yang terlalu tinggi akan menyebabkan penurunan daya beli uang (purchasing power of money) sehingga akan menyebabkan tingkat pendapatan riil yang diperoleh investor atas investasi akan berkurang (Kewal, 2012). Menurut Tandelilin (2010) meningkatnya inflasi merupakan sinyal negatif bagi para investor di pasar modal, sebab jika peningkatan biaya produksi lebih tinggi daripada peningkatan harga produk, maka profitabilitas perusahaan akan turun. Pendapat ini didasarkan pada asumsi bahwa inflasi yang terjadi adalah demand pull inflation, yaitu karena adanya kelebihan permintaan atas penawaran barang yang tersedia. Pada keadaan ini, perusahaan dapat melakuan pembebanan peningkatan biaya kepada konsumen dengan proporsi yang lebih besar sehingga keuntungan perusahaan meningkat, kemampuan perusahaan untuk membayar dividen tinggi dan akan memberikan penilaian positif pada harga saham perusahaan, 
sehingga minat investor berinvestasi pada saham akan meningkat yang akan menyebabkan Indeks Harga Saham Gabungan (IHSG) akan naik (Jayanti, dkk, 2014).

\section{SIMPULAN DAN SARAN}

Berdasarkan hasil penelitian menunjukkan bahwa Kurs Rupiah dan Dollar, Tingkat Inflasi, Jumlah Uang Beredar signifikan dan memiliki hubungan dinamis dengan arah positif, sedangkan untuk variabel Sertifikat Bank Indonesia tidak signifikan namun memiliki hubungan dinamis dengan arah negatif.

Saran Bagi investor yang hendak melakukan investasi pada pada pasar modal, disarankan untuk lebih mempertimbangkan informasi yang berasal dari dalam negeri (internal) seperti tingkat inflasi, tingkat suku bunga SBI, nilai tukar rupiah dan indikator yang berasal dari luar negeri (eksternal) seperti indeks pasar modal negara lain. Informasi tersebut diperlukan untuk memprediksi fluktuasi IHSG yang diperlukan untuk pengambilan keputusan yang tepat.

Penelitian ini masih memiliki kekurangan dan beberapa keterbatasan hasil penelitian dalam menggunakan variabel penelitian ataupun periode sampel pengamatan. Bagi penelitian selanjutnya, disarankan untuk menambah atau mempergunakan indikator variabel yang lain seperti mempertimbangkan faktor internal seperti PDB, tingkat pengangguran, perkembangan ekspor impor dan mempertimbangkan faktor eksternal seperti harga emas dunia, harga minyak dunia, dan indeks bursa negara lain yang dapat menjelaskan pergerakan Indeks Harga Saham Gabungan. Selain itu, disarankan pula untuk menambah periode waktu pengamatan agar dapat memperoleh hasil yang lebih baik.

\section{UCAPAN TERIMA KASIH}

Keberhasilan penelitian ini membutuhkan banyak bimbingan dan bantuan dari banyak pihak dan peneliti berterimakasih dapat menggunakan bantuan dalam menyelesaikan penelitian. Peneliti sangat berterima kasih kepada semua pihak yang tidak dapat kami sebutkan satu per satu yang telah membantu dalam menyelesaikan penelitian ini, peneliti ucapkan khususnya kepada DPPM Universitas Islam Indonesia dalam memberikan bantuan secara finansial selama proses penelitian. Peneliti benar-benar bersyukur bahwa peneliti berhasil menyelesaikan penelitian ini dengan benar. Akhir kata, peneliti ingin mengucapkan terima kasih kepada pihak-pihak terlibat dalam penyelesaian penelitian ini.

\section{DAFTAR PUSTAKA}

Adaramola \& Olugbenga, A., (2013). The Impact of Macroeconomic Indicators on Stock Prices in Nigeria. Developing Country Studies. Vol 1(2): 1-15

Adisetiawan, R., (2018), Kausalitas Ekonomi Makro dan Globalisasi Terhadap Pasar Modal Indonesia. Ekonomis: Jurnal of Economics and Business Vol. 2(1): 66-80.

Anriansyah, I., Siregar, H., dan TB Nur Ahmad Maulana, A.N TB., (2018) Pengaruh Guncangan Makroekonomi Terhadap Integrasi Pasar Modal Di ASEAN. Jurnal Aplikasi Manajemen dan Bisnis, Vol. 4(1)

Arghyrou M.G., Pourpourides P., (2015). Inflation Announcements And Asymmetric Exchange Rateresponses. International Finance. Markets, Institutional. and Money .

Artha, R. D., Achsani, A.N., dan Sasongko, H., (2014). Analisis Fundamental, Teknikal dan Makroekonomi Harga Saham Sektor Pertanian. JMK Jurnal Manajemen Kewirausahaan, Vol. 16:2: $175-184$

Atik, Y.A.I., (2012). Pengaruh Inflasi, Nilai Tukar, dan Tingkat Suku Bunga Sbi Terhadap Harga Saham Perbankan yang Terdaftar di Bursa Efek Indonesia (BEI). Jurusan Manajemen Fakultas Ekonomi Universitas Gunadarma.:1-12.

Bahloul, Slah., Mroua, Mourad and Naifar, Nadir. (2017). The Impact of Macroeconomic and Conventional Stock Market Variabels on Islamic Index return under Regime Switching. Borsa Istanbul Review. 17(1): 62-74

Binnera J.M., Tepper P.T., Andersond R., Jones B., Kendall G., (2010). Does money matter in inflation forecasting?. Physica A 389 (2010) 4793-4808

Boediono. (2005). Ekonomi Moneter. Yogyakarta: BPFE

Buffie, E.F., Aiurado M.,dan Zanna, F. 2017.Inflation Targeting and Exchange Rate Management Management in Less Developed Countries. Journal of International Money and Finance.: 1-68.

Divianto. (2013). Analisis Pengaruh Tingkat Inflasi, Tingkat Suku Bunga SBI, dan Nilai Kurs Dollar AS (USD) Terhadap Indeks Harga Saham Gabungan (IHSG) Di Bursa Efek Indonesia. Jurnal Ekonomi dan Informasi Akuntansi. Vol 3(2): 165-197

Jayanti, Yusnita, Darminto dan Nengah Sudjana. (2014). Pengaruh Tingkat Inflasi, Tingkat Su- 
ku Bunga Sbi, Nilai Tukar Rupiah, Indeks Dow Jones, Dan Indeks Klse Terhadap Indeks Harga Saham Gabungan (IHSG) Studi Pada Bursa Efek Indonesia Periode Januari 2010-Desember 2013. Jurnal Administrasi Bisnis (JAB). Vol. 11(1).

Karim, F.A., Hermanto, dan I.N., Ardana (2018), Pengaruh Faktor Fundamental Makro dan Mikro Terhadap Nilai Perusahaan (Studi PAda Saham Perusahaan Sektor Infrastruktur dan Sektor Konstruksi Yang Terdaftar di BEI Periode 20152017). Jurnal Magister Manajemen Unram, Vol. 7(2): 86-102

Kasman, S., Gulin, dan Gokce, T., (2011). The Impact Of Interest Rate And Exchange Rate Volatility On Banks' Stock Returns And Volatility: Evidence From Turkey. Economic Modeling. Vol 28: 1328-1334

Kewal, Suramaya Suci. (2012). Pengaruh Inflasi, Suku Bunga, Kurs dan Pertumbuhan PDB Terhadap Indeks Harga Saham Gabungan. Jurnal Economia. Vol 8(1): 53-64.

Madura, Jeff. (2009). Keuangan Perusahaan Internasional. Jakarta: Salemba Empat.

Manullang. (2008). Dasar-Dasar Manajemen. Yogyakarta: Ghalia Indonesia (GI)

Martinez. Moya Pablo, Lapena, Ferrer Roman. and Sotos, Escribano Fransisco., (2015). Interest Rate Changes and Stock Return in Spain: A Wavelet Analysis. Business Reasearch Quarterly. 18: 95110

Maryanne, D.M.D. (2009). Pengaruh Nilai Tukar Rupiah, Suku Bunga SBI, Volume Perdagangan Saham, Inflasi dan Beta Saham Terhadap Harga Saham. Tesis Program Magister Manajemen Universitas Diponegoro Semarang.

Mohamad, Firdaus. (2004). Ekonometrika Suatu Pendekatan Aplikatif. Jakarta : Bumi Aksara

Murtini dan Septivanie. (2016). Sensitivitas Dollar, Yuan, Yen dan SBI Terhadap IHSG. Jurnal Riset Akuntansi dan Keuangan. Volume 12(2): 131-140

Nguyen VB. (2015). Effects Of Fiscal Deficit And Money M2 Supply On Inflation: Evidence From Selected Economies Of Asia. Journal of Economics, Finance and Administrative Science 20: 49-53.

Ramadhan, L.T. (2011). Pengaruh Variabel Mikro dan Makro Ekonomi terhadap Defensive Stock Price dan Cyclical Stock Price Pada Perusahaan yang Terdaftar di Bursa Efek Indonesia. Karya Ilmiah, STIE Perbanas Surabaya.

Saputra R.A., Harjito D.A., (2015). Hubungan Kausalitas Antara Nilai Tukar Dengan Harga Sa- ham Dan Inflasi Di Indonesia. Jurnal Manajemen Bisnis Indonesia Vol. 3(1)

Sugiyono. (2010). Metode Penelitian Kuantitatif Kualitatif \& RND. Bandung: Alfabeta

Suselo, D., Djazuli, A, dan Indrawati, K.N., (2015), Pengaruh Variabel Fundamental dan Makro Ekonomi terhadap Harga Saham (Studi pada Perusahaan yang Masuk dalam Indeks LQ45). Jurnal Aplikasi Manajemen (JAM), Vol. 13(1): 104-116

Tandelilin, E., (2010). Portofolio dan Investasi : Teori dan Aplikasi. Edisi 1. Yogyakarta: Kanisius 